\title{
Use of RESRAD-Onsite 7.2 Code to Assess Environmental Risk around Tudor Shaft Mine Tailing Sites
}

\author{
Raymond Limen Njinga ${ }^{1,2}$ \& Victor Makondelele Tshivhase ${ }^{1}$ \\ ${ }^{1}$ Centre for Applied Radiation Science and technology, North West University, Mafikeng, South Africa \\ ${ }^{2}$ Department of Physics, Federal University Dutse, Jigawa State, Nigeria \\ Correspondence: Raymond Limen Njinga, Centre for Applied Radiation Science and technology, North West \\ University, Mafikeng, South Africa. E-mail: njingaraymond@yahoo.co.uk
}

Received: April 3, 2018

doi:10.5539/enrr.v8n3p138
Accepted: April 22, 2018

URL: https://doi.org/10.5539/enrr.v8n3p138

\begin{abstract}
The RESRAD-onsite 7.2 code has been used to assess the total dose rate in Tudor shaft site contaminated over an area of $10 \mathrm{~km}^{2}$. The risk analysis simulation was span over a period of $1.0 \mathrm{E}+3$ years. The maximum total dose of $1.64 \mathrm{mSv} / \mathrm{yr}$ was obtain at $\mathrm{t}=8.17 \pm 0.02$ years. The total peak dose at time $\mathrm{t}=0 \mathrm{yr}$. is $1.63 \pm 1.0 \mathrm{mSv} / \mathrm{yr}$ for all pathways. This value is 6.53 times higher compare to the basic radiation dose limit of $2.5 \mathrm{E}-01 \mathrm{mSv} / \mathrm{yr}$. The evaluated excess cancer risk was $3.46 \mathrm{E}-3$ and is 10 times higher compared to the recommended limit of WHO. A cover layer depth of $1.25 \mathrm{~m}$ was simulated using the code and a total maximum peak dose for all pathways was $2.52 \mathrm{E}-01 \mathrm{mSv} / \mathrm{yr}$ at $\mathrm{t}=5.0 \mathrm{E}+2 \pm 1.0$ years.
\end{abstract}

Keywords: RESRAD code, peak dose, distribution coefficient, excess cancer risk, contaminated site

\section{Introduction}

A primary consideration in formulating key environmental decisions and policies depends on potential risk to human health and the environment (Bellamy et al., 2014). Studying the possible impacts resulting from exposure to ${ }^{238} \mathrm{U},{ }^{226} \mathrm{Ra}$, ${ }^{232} \mathrm{Th}$ and ${ }^{40} \mathrm{~K}$ often requires the modelling of the contaminant transport in the environment. According to literature the South African gold mines are associated with high levels of radionuclides. The mining activities in general tend to elevate the concentrations of NORMS near the earth surface (Njinga et al., 2016).

Tudor Shaft is an informal settlement in Krugersdorp which is west of Johannesburg and is highly contaminated by ${ }^{238} \mathrm{U},{ }^{226} \mathrm{Ra},{ }^{232} \mathrm{Th}$ and ${ }^{40} \mathrm{~K}$ due to the gold mine shaft and tailings dam. The community are affected by this mine's legacy. It is very obvious that people built their shacks on the tailings soil and grow their vegetables (resident farmer). There are children playing on the soils almost on daily bases which could result in soil ingestion. There are streams, wells and boreholes used by the population for irrigation, drinking, and household usages. The National Nuclear Regulator (NNR) in 2012, acting on advice from the local government began removing the Tudor Shaft waste dump. About half of the soil was removed, but environmentalists were alarmed that it was being done without risk-assessment studies or consultations.

${ }^{238} \mathrm{U},{ }^{226} \mathrm{Ra},{ }^{232} \mathrm{Th}$ and ${ }^{40} \mathrm{~K}$ are common contaminants of concern due to its potential of high mobility in the environment. Dose assessment modelling of Tudor Shaft soil contamination with ${ }^{238} \mathrm{U},{ }^{226} \mathrm{Ra},{ }^{232} \mathrm{Th}$ and ${ }^{40} \mathrm{~K}$ would yield radiation dose results to indicate either a low soil clean up level that might require intensive remediation to attain, or a low waste acceptance criterion that would restrict the disposal of ${ }^{238} \mathrm{U},{ }^{226} \mathrm{Ra}$, ${ }^{232} \mathrm{Th}$ and ${ }^{40} \mathrm{~K}$ contaminated material in the soil (Gil-Garcia et al., 2009).

The RESRAD onsite code is developed by the U.S. Department of Energy (DOE) and the U.S. Nuclear Regulatory Commission (NRC) to evaluate radiologically contaminated sites (Yu et al., 2001a; Yu 1999, 2006, 2007). The code is used to derive clean-up criteria or Derived Concentration Guideline Levels (DCGLs) and estimate radiation dose or risk from residual radioactive material under various scenarios using appropriate parameters such as the cover materials with a total thickness, contamination depth, saturated zones, unsaturated zones, landfill spans an area and so on.

RESRAD have been widely used throughout the world for numerous benchmarking, verification, and validation studies. Recently, the U.S. Environmental Protection Agency (EPA) Office of Superfund Remediation and 
Technology Innovation (OSRTI) issued a Memorandum (Office of Solid Waste and Emergency Response 9285.6-20) providing updated guidance on "Radiation Risk Assessment at Comprehensive Environmental Response, Compensation, and Liability Act (CERCLA) Sites (EPA 2014). The RESRAD code calculates both radiological dose and risk (NAS, 1999, Yu 1999, 2006, Walker, 2013). The dose assessments due ${ }^{238} \mathrm{U},{ }^{226} \mathrm{Ra}$,

${ }^{232} \mathrm{Th}$ and ${ }^{40} \mathrm{~K}$ concentration in the soils would be analysed using RESRAD modelling for on-site exposures for the following pathways; external gamma, plant ingestion, meat ingestion, milk ingestion, drinking water and soil ingestion.

The aim of this study is to analyse the activity concentration of ${ }^{238} \mathrm{U},{ }^{226} \mathrm{Ra},{ }^{232} \mathrm{Th}$ and ${ }^{40} \mathrm{~K}$ over an area of $10 \mathrm{~km}$ and show how the $\mathrm{k}_{\mathrm{ds}}$ values of ${ }^{238} \mathrm{U},{ }^{226} \mathrm{Ra},{ }^{232} \mathrm{Th}$ and ${ }^{40} \mathrm{~K}$ for the loamy soil type contribute to the peak dose in the contaminated zone. It further evaluate the pathway contributions to the peak dose, when it occur over a span of 1000 years and calculate the excess lifetime cancer risk. Finally the study evaluates how the contaminated site could be clean using a clean cover layer of $1.25 \mathrm{~m}$ (depth) of soil so that the area would be use in farming and other basic activities and the people leave without any fear of health hazards.

\section{Materials and Methods}

\subsection{The Study Area}

The study area is in Krugersdorp (26 $6^{\prime} \mathrm{S}$ and $\left.27^{\circ} 46^{\prime} \mathrm{E}\right)$ and is a mining community in the West Rand District of Gauteng Province. The region covers a total area of $247.2 \mathrm{~km}^{2}$ with about 140,643 people and population density of 570 persons per $\mathrm{km}^{2}$ (Turton, 2004). In terms of geological arrangement, the West Rand area of Gauteng is underlain by rocks of the Johannesburg Subgroup of the Witwatersrand Super-group and is made up of erosion resistant quartzites, ironstones and some marine lava deposits interspersed with softer, more easily eroded tillites, mudstones and conglomerates and are high in water infiltration rate (Moore \& Ramamoorthy, 1984). In some of the conglomerates of the younger members of the Super-group is found huge deposits of gold (Mendelsohn $\&$ Potgieter, 1986). Some of the minerals that have been associated with gold mining in the study area are pyrite and uranite. The map of the study area showing field sampling information is shown in Figure 1.

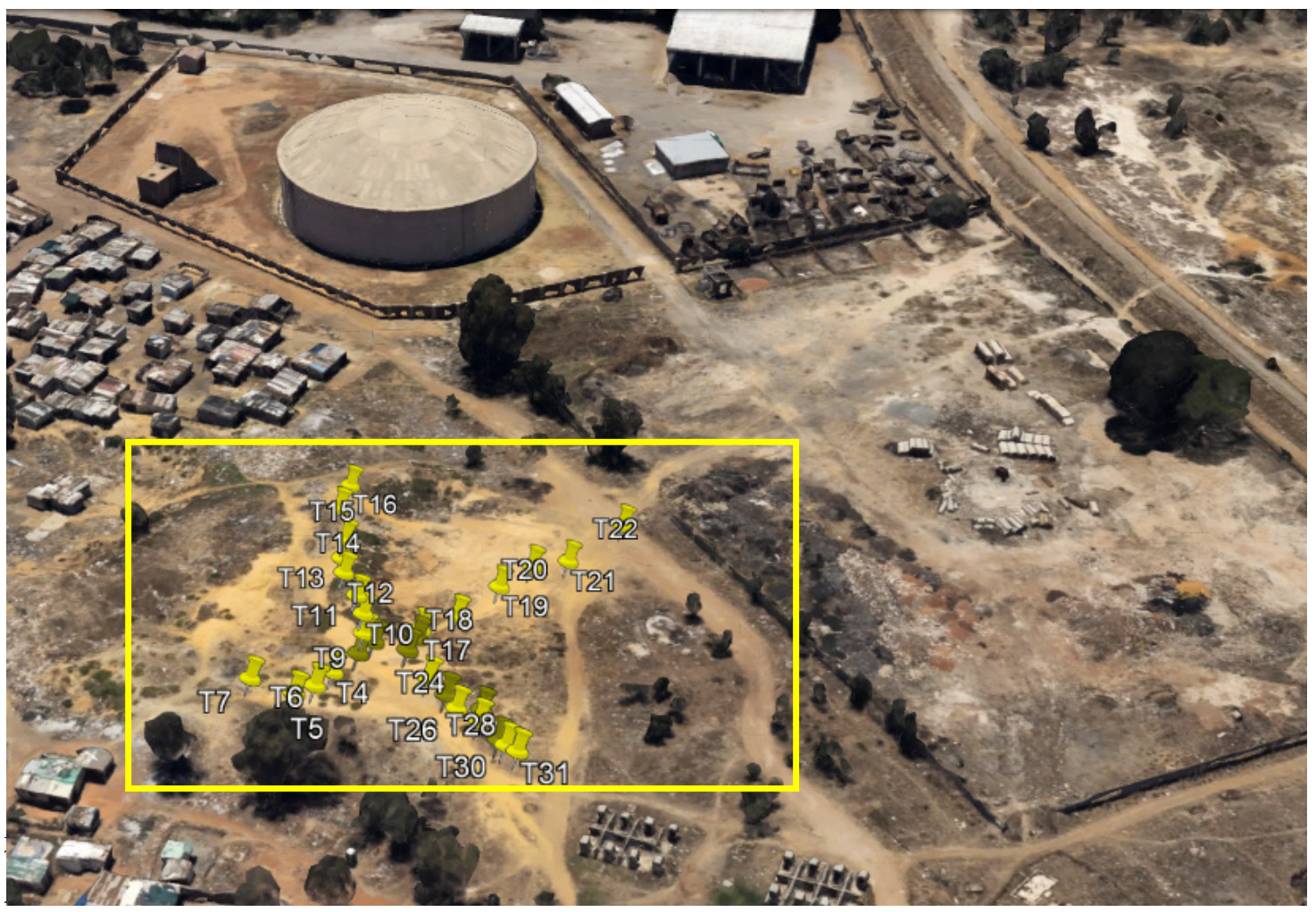

Figure 1. Map of the study area showing some field sampling information and the area of coverage

Gold mining has left more than 200 tailings dumps in the West Rand region where Krugersdorp is located for decades (Venter, 1995). The soil is composed mostly of sand with particle size $>63 \mu \mathrm{m}$, silt with particle size $>$ 
$2 \mu \mathrm{m}$, and a smaller amount of clay with particle size $<2 \mu \mathrm{m}$ and can be classified as loamy soil type. By weight, its mineral composition is about $40 \%$ concentration of sand, $40 \%$ concentration of silt and $20 \%$ concentration of clay. The soil is suitable for growing most plant varieties.

\subsection{Rate of Radionuclide Release from the Contaminated Zone}

The release rate of radionuclides from the contaminated zone is estimated by using a nuclide dependent, first-order leach rate constant, which is defined as the fraction of available radionuclide $i$ leached out per unit of time. The radionuclide release rate can be written as:

$$
\frac{R_{i}(t)}{d t}=L_{i} \times \rho_{b} \times A \times T(t) \times S_{i}(t)
$$

where; $L_{i}=$ leach rate for radionuclide $\mathrm{i}\left(\mathrm{yr}^{-1}\right), \rho_{b}=$ bulk density of the contaminated zone $\left(\mathrm{kg} / \mathrm{m}^{3}\right), A=$ area of the contaminated zone $\left(\mathrm{m}^{2}\right), T(t)=$ thickness of the contaminated zone at time $t(\mathrm{~m})$, and $S_{i}(t)=$ average concentration of the $i^{\text {th }}$ principal radionuclide in the contaminated zone available for leaching at time $t$.

The first-order leach rate constant used in RESRAD is time independent radionuclide leach rate constant. It is estimated on the basis of the soil residence time for the initial thickness of the contaminated zone and is written as;

$$
L_{i}=\frac{I}{V_{w c} \times T_{0} \times R_{f}}=\frac{\left(1-C_{e}\right) \times\left[P_{r} \times\left(1-C_{r}\right)+I_{r}\right]}{V_{w c} \times T_{0} \times R_{f}}
$$

where; $I=$ infiltration rate $(\mathrm{m} / \mathrm{yr}), V_{w c}=$ volumetric water content of the contaminated zone defined as the product of the saturated water content of the contaminated zone $V_{w c}^{S}$ and the saturation ratio of the contaminated zone $R_{s}$. The saturated water content $V_{w c}^{S}$ is defined as the water content when the soil material is saturated. Hence, the saturated water content of the contaminated zone $V_{w c}^{s}$ is equals to the total porosity $P_{t}$ of the soil material.

$T_{0}=$ initial thickness of the contaminated zone $(\mathrm{m}), R_{f}=$ retardation factor in the contaminated zone for $i$-radionuclide, $C_{e}=$ evapotranspiration coefficient, $C_{r}=$ runoff coefficient (dependent on the environmental setting and the slope of the contaminated zone) $P_{r}=$ precipitation rate (annual rainfall), and $I_{r}=$ irrigation rate $(\mathrm{m} / \mathrm{yr})$.

When the medium is saturated, then the saturation ratio of the contaminated zone $R_{s}$ equals unity. Under unsaturated infiltration conditions, the saturation ratio is a function of the infiltration rate, the saturated hydraulic conductivity, and the texture of the soil. The saturation ratio can be estimated by using the following equation (Clapp and Hornberger 1978):

$$
R_{s}=\left[\frac{I}{H_{C}^{S}}\right]^{\frac{1}{2 b+3}}
$$

where; $H_{C}^{S}=$ saturated hydraulic conductivity $(\mathrm{m} / \mathrm{yr}), b=$ soil-specific exponential parameter.

The retardation factor for radionuclide $i, R_{f_{i}}$ is the ratio of the average pore water velocity to the radionuclide transport velocity. Assuming that the adsorption-desorption process can be represented with a linear isotherm; the retardation factor can be calculated with the following formula (Yu 1987, 1999):

$$
R_{f_{i}}=1+\frac{\rho_{b} k_{d_{i}}}{V_{w c}}=1+\frac{\rho_{b} k_{d_{i}}}{P_{t} R_{S}}
$$

where; $k_{d_{i}}$ is the distribution coefficient for the $i^{\text {th }}$ principal radionuclide $\left(\mathrm{cm}^{3} / \mathrm{g}\right)$.

From the above explanations, it is known that leach rate of a radionuclide is determined by its $k_{d_{i}}$ value, which decides the relative transport speed of the radionuclide to that of water in the pore space. The leach rate also depend on the water infiltration rate, which determines the capacity of the liquid phase in soil, soil properties such as bulk density, porosity, saturated hydraulic conductivity, and the b-parameter (Eq 3) and the extent of contamination, which is described by contaminated zone thickness, area, and radionuclide concentration. 


\subsection{Hydrogeological and Hydro geochemical Properties}

The hydrogeological and hydro geochemical properties of the zone that lie below the contaminated zone are assumed the same as those of the saturated stratum. The RESRAD code allows up to five horizontal strata below the contaminated zone, that is, $\mathrm{n}$ is $\leq 5$. If $\mathrm{n}=0$, the contaminated zone extends down to the aquifer. The distance from the ground surface to the water table, $D_{w r}(t)$, at time $t$ is evaluated using the relation below;

$$
D_{w r}(t)=C_{d}(t)+T(t)+\sum_{m=1}^{n+1} \Delta z_{m}
$$

where; $C_{d}(t)=$ cover depth at time $t(\mathrm{~m})$, and $T(t)=$ thickness of contaminated zone at time $t(\mathrm{~m})$.

\section{Materials and Methods}

\subsection{Collection of Soil Samples}

The 145 soil samples were collected according to the internationally established experience as shown in Figure 1 over an area of $10 \mathrm{~km}^{2}$. For each soil sample collected, an area of about $0.5 \mathrm{~m} \times 0.5 \mathrm{~m}$ was marked and carefully cleared of debris to a few-meter depth $(0.30 \mathrm{~m})$ before collection of the soil samples. At the centre of each marked area, two $\mathrm{kg}$ of soil was collected using an auger at a depth of about $0.15 \mathrm{~m}$ from the ground so as to get the natural soil. Each soil sample was labeled according to the geographical coordinates of the sampling area. The $2 \mathrm{~kg}$ soil samples each making a total of 145 soil samples were transported to the Centre for Applied Radiation and Technology (CARST) laboratory at North-West University, South Africa, for analysis.

In CARST, the soil samples were crushed into fine powder using a mortar and pestle. The fine form of each soil sample was obtained using a scientific sieve of $0.2-\mathrm{mm}$ mesh, dried in an oven at about $383{ }^{\circ} \mathrm{K}$ for 24 hours, hermetically sealed in standard $1500 \mathrm{~mL}$ plastic Marinelli beakers (assuming that radioactivity is homogeneously distributed in the whole volume of the measuring samples), dry-weighed and stored for about four weeks prior to counting to allow radioactive equilibrium among radon $\left({ }^{222} \mathrm{Rn}\right)$, thoron $\left({ }^{220} \mathrm{Rn}\right)$, and their short lived progenies. On average, $1.25 \mathrm{~kg}$ of soil was taken from each sample and put into $1.50 \mathrm{~L}$ Marinelli beakers for measurements using the HPGe detector.

\subsection{Calibration of the Low Background Counting System}

The calibration of the low background counting system was done using standard reference materials (SRM) from the International Atomic Energy Agency. The detector is a co-axial n-type and has a resolution of $2.0 \mathrm{keV}$ at $1332 \mathrm{keV}$ of ${ }^{60} \mathrm{Co}$ with a relative efficiency of $20 \%$. The output of the detector was analyzed using Canberra Genie 2000 software (Genie ${ }^{\mathrm{TM}}$ 2000). The detector is lead shielded to reduce the background level of the system (Xinwei and Xiaolon 2008). The efficiency calibration of the system was carried out using standard source of uranium ore in same geometry of our samples and the values plotted against energy for particular geometry. The full energy peak efficiency of a high purity Germanium (HPGe) detector is the number of gamma rays detected by the detector to the number of photons emitted by the source for a specific energy expressed mathematically as:

$$
\varepsilon(E)=n(E) \times\left(A \times I_{\gamma}\right)^{-1}
$$

where, $n(E)=$ net count rate of the photo peak for the corresponding energy $E, I \gamma=$ Intensity of the gamma energy, $\mathrm{A}=$ present activities of the standard reference source.

For the evaluation of the efficiency of the detector (HPGe), the contributions for the coincidence summing effect, angular correlations due to the cascading gamma-rays were taken into account. The SRM uranium in silica matrix (RGU-1), thorium in silica matrix (RGTh-1) and potassium sulphate (RGK-1) with the same diameter as the soil samples of known concentrations of ${ }^{238} \mathrm{U},{ }^{232} \mathrm{Th}$ and ${ }^{40} \mathrm{~K}$ radionuclides supplied by the Canada Centre for Mineral and Energy Technology (CAMET) under a contract with the IAEA were used for the calibration of detector efficiencies.

\subsection{Activity Concentrations of Soil Samples}

The radioactivity of each sample was measured using the calibrated HPGe-detector. Keeping the samples one by one on the top of the detector and counted for a period of 10,000 s the activity concentration of each radionuclide in the sample was determined by using the net count rates $(\mathrm{Nc})$. After subtracting the background counts from the gross counts for the same counting time under the selected photo peaks, weight of the sample, the photo-peak 
efficiency and the gamma intensity at a specific energy, a Computer software programming (GENE 2000) was used to analysed ${ }^{226} \mathrm{Ra},{ }^{232} \mathrm{Th},{ }^{238} \mathrm{U}$ and ${ }^{40} \mathrm{~K}$.

The activity concentration of ${ }^{226} \mathrm{Ra}$ was determined using a photon peak of $609 \mathrm{keV}$ (46.1\%) from ${ }^{214} \mathrm{Bi}$. Concentration of ${ }^{232} \mathrm{Th}$ was determined using the weighted mean of the gamma-ray transitions associated with the decays of ${ }^{228} \mathrm{Ac},{ }^{212} \mathrm{~Pb}$ and ${ }^{208} \mathrm{Tl} .{ }^{238} \mathrm{U}$ was determined from the average concentrations of the ${ }^{214} \mathrm{~Pb}$ and ${ }^{214} \mathrm{Bi}$ decay products (Hamby and Tynybekov, 2000; Tzortzis et al., 2003). The ${ }^{40} \mathrm{~K}$ concentration was determined using the gamma transition of $1461 \mathrm{keV}(10.7 \%)$. Following the spectrum analysis, count rates for each detected photo peak and activity per unit mass (specific activity or radiological concentration) for each of the detected nuclides are calculated (Tzortzis et al., 2003). Thus, for each sample studied the specific activity concentrations of the ${ }^{226} \mathrm{Ra},{ }^{232} \mathrm{Th},{ }^{238} \mathrm{U}$ and ${ }^{40} \mathrm{~K}$ radionuclides are determined in units of $\mathrm{Bq} / \mathrm{kg}$ according to the expression below (Olise et al., 2010):

$$
A=\frac{C_{N P}}{B I \times \mathcal{E}\left(E_{\gamma}\right) \times m}
$$

where $C_{N P}=$ net peak counts for a given energy line, $B I=$ branching intensity, $\varepsilon\left(E_{\gamma}\right)=$ the absolute photo-peak efficiency of the detector and $m$ is the mass of the sample in $\mathrm{kg}$.

The calculation of external exposure from the specific activity concentrations of the ${ }^{226} \mathrm{Ra},{ }^{232} \mathrm{Th},{ }^{238} \mathrm{U}$ and ${ }^{40} \mathrm{~K}$ radionuclides determined in units of $\mathrm{Bq} / \mathrm{kg}$ in RESRAD-Onsite 7.2 Code is based on the dose conversion factors and the formula obtained from the US Federal Guidance Report-12 (FGR-12) as published by Keith and Jeffrey (1993).

\subsection{Quality Control}

In order to perform quality control, a sample with known radionuclides concentrations were analysed using the same procedures. Based on the soil samples in this study the standard reference material IAEA-RGK-1, IAEA-RGTh-1, and IAEA-RGU-1 were analysed for using the gamma ray spectrometry system and the results compared in level of confidence with known radionuclides concentrations in the certificates.

\subsection{Input Parameters}

The radionuclide transformation was based on the International Commission on Radiological Protection-38 library (ICRP 2008), Federal Guidance Report (FGR) $11 \& 12$ for internal and external dose conversion library and FGR 13 library for health risk. The cut-off half-life was set to 180 days (6 months). This was based on the radionuclide in this study $\left({ }^{238} \mathrm{U},{ }^{226} \mathrm{Ra},{ }^{232} \mathrm{Th}\right.$ and $\left.{ }^{40} \mathrm{~K}\right)$ with a cut-off half-life of six months as shown in Table 1 .

Table 1. Principal and associated radionuclides with a cut-off half-life of 6 months

\begin{tabular}{|c|c|c|}
\hline \multicolumn{2}{|c|}{ Principal Radionuclide $^{\mathrm{a}}$} & \multirow[t]{2}{*}{ Associated Decay Chain ${ }^{b}$} \\
\hline Species & Half-life (yr) & \\
\hline${ }^{40} \mathrm{~K}$ & $1.28 \mathrm{E}+09$ & - \\
\hline \multirow[t]{7}{*}{${ }^{226} \mathrm{Ra}$} & $1.60 \mathrm{E}+03$ & ${ }^{226} \mathrm{Ra} 1.60 \times 10^{3}{ }^{222} \mathrm{Rn}(3.8235 \mathrm{~d})$ \\
\hline & & ${ }^{218} \mathrm{Po}(3.05 \mathrm{~min})$ \\
\hline & & {$\left[{ }^{214} \mathrm{~Pb}(99.98 \%, 26.8 \mathrm{~min})\right.$} \\
\hline & & $\left.{ }^{218} \mathrm{At}(0.02 \%, 2 \mathrm{~s})\right]$ \\
\hline & & ${ }^{214} \mathrm{Bi}(19.9 \mathrm{~min})$ \\
\hline & & {$\left[{ }^{214} \mathrm{Po}\left(99.98 \%, 1.64 \times 10^{-4} \mathrm{~s}\right)\right.$} \\
\hline & & $\left.{ }^{210} \mathrm{Tl}(0.02 \%, 1.3 \mathrm{~min})\right]$ \\
\hline${ }^{232} \mathrm{Th}$ & $1.41 \mathrm{E}+10$ & - \\
\hline \multirow[t]{3}{*}{${ }^{238} \mathrm{U}$} & $4.47 \mathrm{E}+09$ & ${ }^{234} \mathrm{Th}(24.10 \mathrm{~d})$ \\
\hline & & {$\left[{ }^{234 \mathrm{~m}} \mathrm{~Pa}(99.80 \%, 1.17 \mathrm{~min})\right.$} \\
\hline & & $\left.{ }^{234} \mathrm{~Pa}(0.33 \%, 6.7 \mathrm{~h})\right]$ \\
\hline
\end{tabular}

a Radionuclides with half-lives greater than six months.

${ }^{b}$ The chain of decay products of a principal radionuclide extending to (but not including) the next principal radionuclide or a stable nuclide. Half-lives are given in parentheses. Branches are indicated by square brackets with branching ratios in parentheses. 
The use of site-specific parameter and defaults values obtained from literature were used for dose assessments (Yu et al., 2000) as shown in Table 2. However, the distribution coefficients $\left(\mathrm{k}_{\mathrm{ds}}\right)$ of ${ }^{238} \mathrm{U},{ }^{226} \mathrm{Ra},{ }^{232} \mathrm{Th}$ and ${ }^{40} \mathrm{~K}$ of the three zones (contaminated, saturated and unsaturated) were set to $15 \mathrm{~cm}^{3} / \mathrm{g}, 36000 \mathrm{~cm}^{3} / \mathrm{g}, 3300 \mathrm{~cm}^{3} / \mathrm{g}$ and 55 $\mathrm{cm}^{3} / \mathrm{g}$ respectively for the loamy soils to evaluate the transport mechanism to the water table.

Table 2. Basic defaults and site specific inputs values used in this study

\begin{tabular}{lll}
\hline Parameters & Site specific data & Default data \\
\hline Area of contaminated zone & $10 \mathrm{~km}^{2}$ & - \\
Thickness of contaminated zone & $0.15 \mathrm{~m}$ & - \\
Cover depth & $1.25 \mathrm{~m}$ & - \\
Length parallel to aquifer flow & 100 & - \\
Density of contaminated zone & $1.5 \mathrm{~g} / \mathrm{cm}^{3}$ & - \\
Contaminated erosion rate & - & $0.001 \mathrm{~m} / \mathrm{yr}$. \\
Contaminated zone total porosity & - & 0.4 \\
Contaminated zone b- parameter & - & 5.3 \\
Evapotranspiration coefficient & - & 0.5 \\
Wind speed & $2 \mathrm{~m} / \mathrm{s}$ & - \\
Precipitation rate & $1 \mathrm{~m} / \mathrm{yr}$ & - \\
Irrigation rate & - & $0.2 \mathrm{~m} / \mathrm{yr}$. \\
Density of saturated zone & $1.5 \mathrm{~g} / \mathrm{cm}$ & \\
Saturated zone total porosity & - & 0.4 \\
Saturated zone effective porosity & - & 0.2 \\
Saturated hydraulic gradient & - & 0.02 \\
Saturated zone b- parameter & - & 5.3 \\
Water table drop rate & - & $0.001 \mathrm{~m} / \mathrm{yr}$. \\
Well pump intake depth & $10 \mathrm{~m}$ & - \\
Exposure duration & - & $30 \mathrm{yrs}$. \\
Indoor time factor & 0.5 & - \\
Outdoor time factor & 0.25 & - \\
Fruits and grains consumption rate & - & $160 \mathrm{~kg} / \mathrm{yr}$. \\
Leafy vegetable consumption rate & - & $14 \mathrm{~kg} / \mathrm{yr}$. \\
Soil ingestion rate & - & $36.5 \mathrm{~g} / \mathrm{yr}$. \\
Drinking water intake & 510 liters/yr. \\
\hline
\end{tabular}

\section{Results and Discussions}

The analysis of ${ }^{40} \mathrm{~K},{ }^{226} \mathrm{Ra},{ }^{232} \mathrm{Th}$ and ${ }^{238} \mathrm{U}$ in the standard reference material IAEA-RGK-1, IAEA-RGTh-1, and IAEA-RGU-1 with known activity concentration of respective reference values in $\mathrm{Bq} / \mathrm{kg}$ evaluated by the gamma ray spectrometry system for quality control leads to good agreement for the radionuclides under validation. The percentage confidence were $95 \%$ for ${ }^{40} \mathrm{~K}, 97 \%$ for ${ }^{238} \mathrm{U}, 98 \%$ for ${ }^{226} \mathrm{Ra}$ and $86 \%$ for ${ }^{232} \mathrm{Th}$. As demonstrated by this technique the four radionuclides were analysed with good level of confidence. The results of the analysed soil samples for the Tudor shaft contaminated site are presented in Table 3.

Table 3. Results of activity concentration $(\mathrm{Bq} / \mathrm{g})$

\begin{tabular}{llll}
\hline Radionuclides & Mean values & Range & Median \\
\hline${ }^{40} \mathrm{~K}$ & $0.035 \pm 0.002$ & $0.023-0.039$ & 0.025 \\
${ }^{226} \mathrm{Ra}$ & $0.915 \pm 0.016$ & $0.690-1.287$ & 0.854 \\
${ }^{232} \mathrm{Th}$ & $0.018 \pm 0.001$ & $0.009-0.021$ & 0.013 \\
${ }^{238} \mathrm{U}$ & $1.404 \pm 0.061$ & $0.974-1.898$ & 1.215 \\
\hline
\end{tabular}

The total peak dose at time $\mathrm{t}=1$ yr. due to ${ }^{238} \mathrm{U},{ }^{226} \mathrm{Ra},{ }^{232} \mathrm{Th}$ and ${ }^{40} \mathrm{~K}$ were $3.35 \mathrm{E}-02 \mathrm{mSv} / \mathrm{yr}, 1.59 \mathrm{mSv} / \mathrm{yr}$, $3.16 \mathrm{E}-03 \mathrm{mSv} / \mathrm{yr}$ and $5.86 \mathrm{E}-03 \mathrm{mSv} / \mathrm{yr}$. The maximum total dose (t-max-D) of $1.64 \mathrm{mSv} / \mathrm{yr}$ was obtain at $\mathrm{t}=$ $8.17 \pm 0.02$ yrs. The meat, milk and soil pathways total dose contributions were $1.496 \mathrm{E}-02 \pm 0.0091,1.547 \mathrm{E}-02$ \pm 0.0094 , and $1.838 \mathrm{E}-02 \pm 0.0112 \mathrm{mSv} / \mathrm{yr}$ respectively. The DCGLs values at $\mathrm{t}=8.17 \pm 0.02$ yrs were calculated 
based the basic radiation dose limit (BRDL) of $0.25 \mathrm{mSv} / \mathrm{yr}$ multiplied by the initial contaminant levels $(\mathrm{Bq} / \mathrm{g})$ of the radionuclides divided by the respective maximum total peak dose at time $t=8.17 \pm 0.02$ yrs. The total DCGLs values at time of maximum total dose (t-max-D) were $3.423 \mathrm{~Bq} / \mathrm{g}$ for ${ }^{238} \mathrm{U}, 1.421 \mathrm{E}-01 \mathrm{~Bq} / \mathrm{g}$ for ${ }^{226} \mathrm{Ra}$, 1.647E-01 Bq/g for ${ }^{232} \mathrm{Th}$ and $1.431 \mathrm{~Bq} / \mathrm{g}$ for ${ }^{40} \mathrm{~K}$.

As seen in Figure 2, the total peak dose at time $\mathrm{t}=1 \mathrm{yr}$. is $1.63 \pm 1.0 \mathrm{mSv} / \mathrm{yr}$ for all pathways summed and is 6.53 times higher compare to the basic radiation dose limit of $2.5 \mathrm{E}-01 \mathrm{mSv} / \mathrm{yr}$.

DOSE: All Nuclides Summed, All Pathways Summed

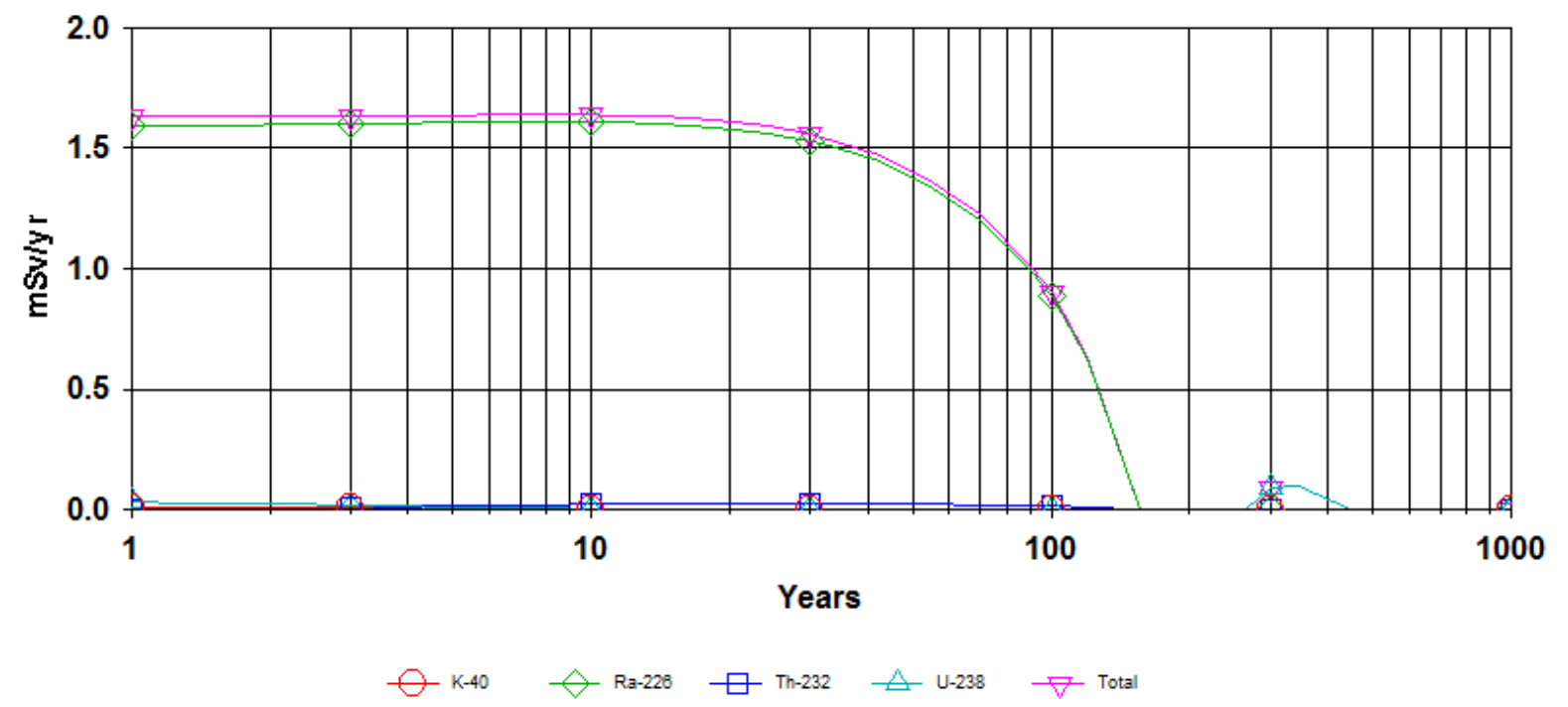

Figure 2. Summed total dose due to all nuclides and all pathways

The evaluated excess cancer risk as revealed in Figure 3, was observe to be constant from the $1^{\text {st }}$ to the $10^{\text {th }}$ year with approximate value of $3.46 \mathrm{E}-3$. The value is 10 times higher compared to the recommended limit of WHO.

EXCESS CANCER RISK: All Nuclides Summed, All Pathways Summed

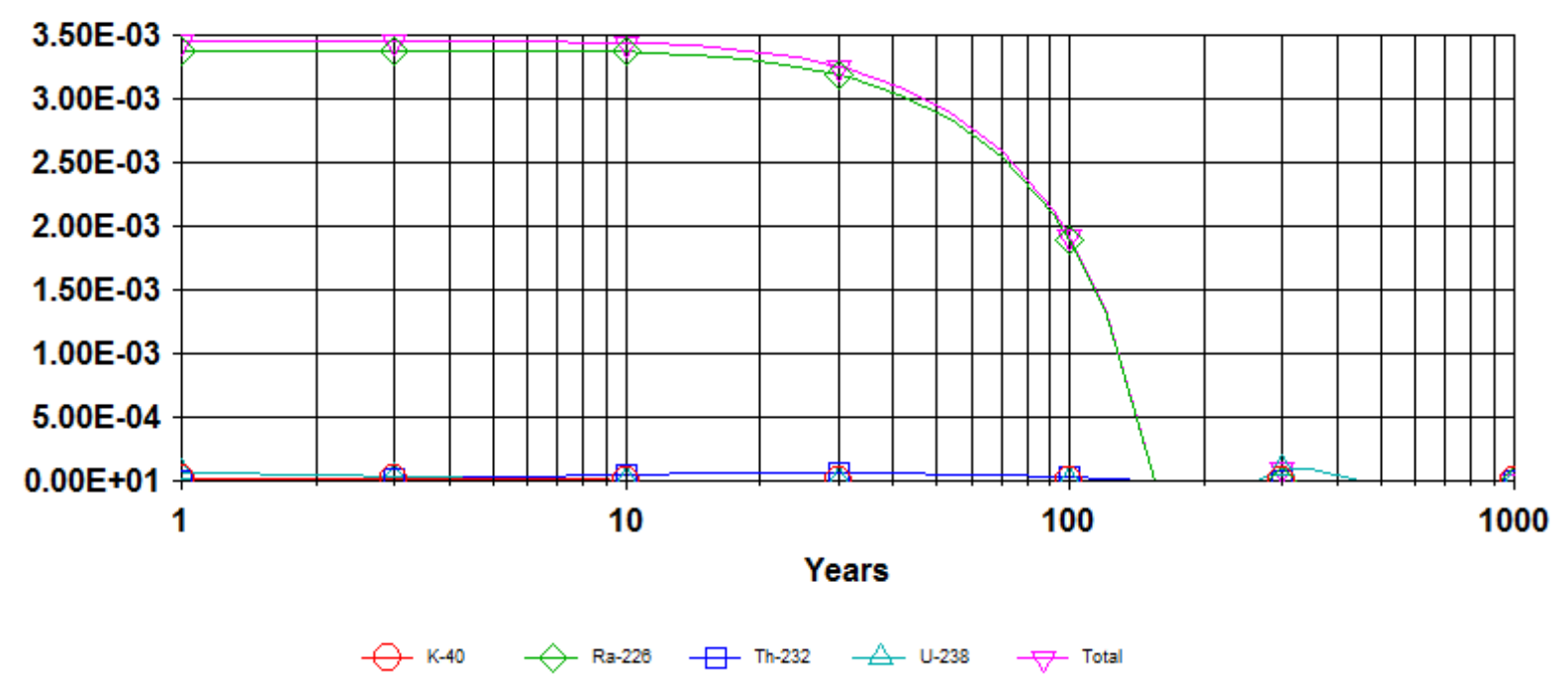

Figure 3. A log-scale plot of excess cancer risk, time, and nuclide contributions

As seen in Figure 2, ${ }^{226} \mathrm{Ra}$ is the major contributor (99.1\%) at the early times to the excess cancer risk with a total value of $3.38 \times 10^{-3}$, which is 10 times the limit of $3.00 \times 10^{-4}$, obtained using recommended value of 0.25 
$\mathrm{mSv} / \mathrm{yr}$. At about 11 years and above, there was a slow drop in the risk values up to the $100 \mathrm{yrs}$ after which the risk was totally below the BRDL estimate.

In the RESRAD modelling, a transfer function is used which calculates the amount of progeny radionuclide in groundwater as observed at a certain time. This may be caused by the existence of parent radionuclide in the contaminated zone at time 0 to 10 yrs since ${ }^{238} \mathrm{U},{ }^{226} \mathrm{Ra},{ }^{232} \mathrm{Th}$ and ${ }^{40} \mathrm{~K}$ are transported in the soils. During these periods, the decay products (progeny radionuclides) also have the potential to dissolve and transported to deeper soils.

The early pathway as observed in Figure 4 is external gamma with a value of $1.39 \mathrm{mSv} / \mathrm{yr}$ at time $\mathrm{t}=1 \mathrm{yr}$ and later followed by plant ingestion (water independent) with a value of $0.42 \mathrm{mSv} / \mathrm{yr}$. Later in the future, they was a drop in contribution from all the pathways considered in this study.

\section{DOSE: All Nuclides Summed, Component Pathways}

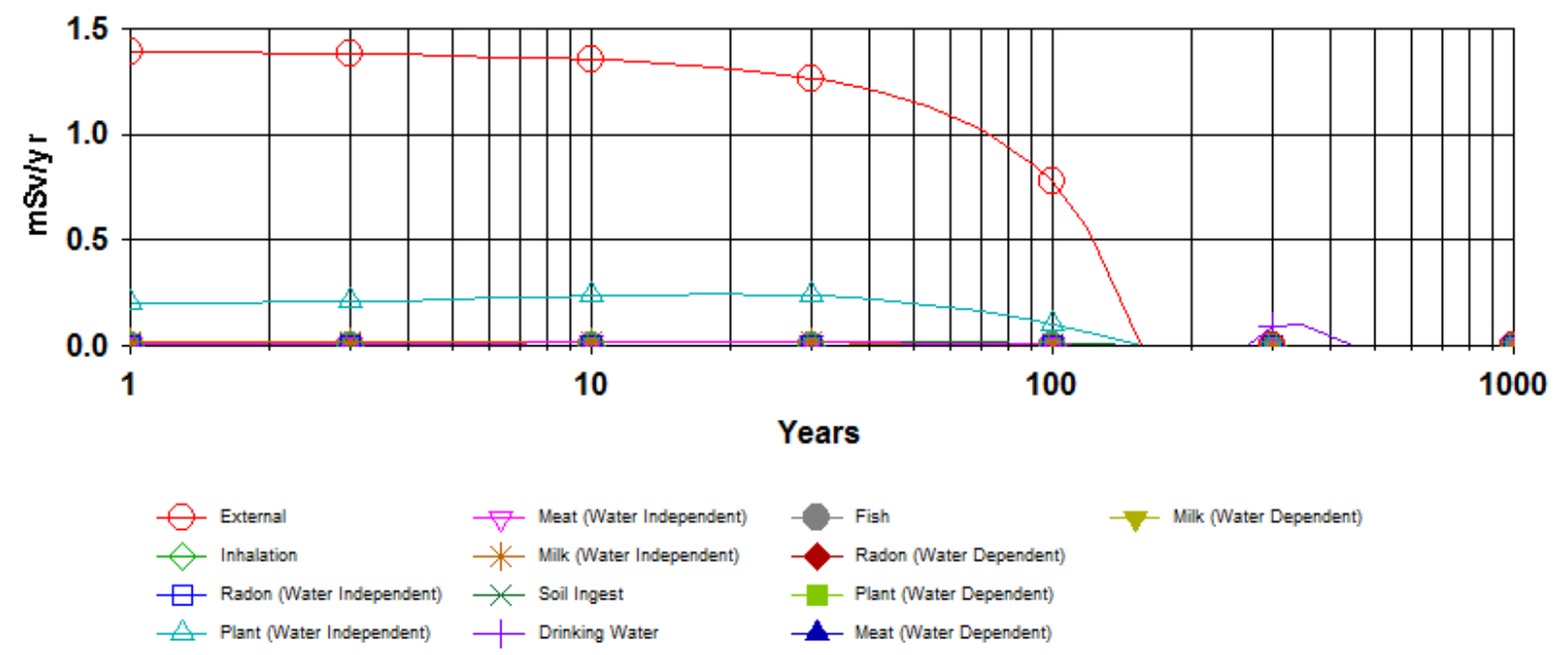

Figure 4. Log-scale plot of the pathway contributions to peak dose

DOSE: All Nuclides Summed, All Pathways Summed

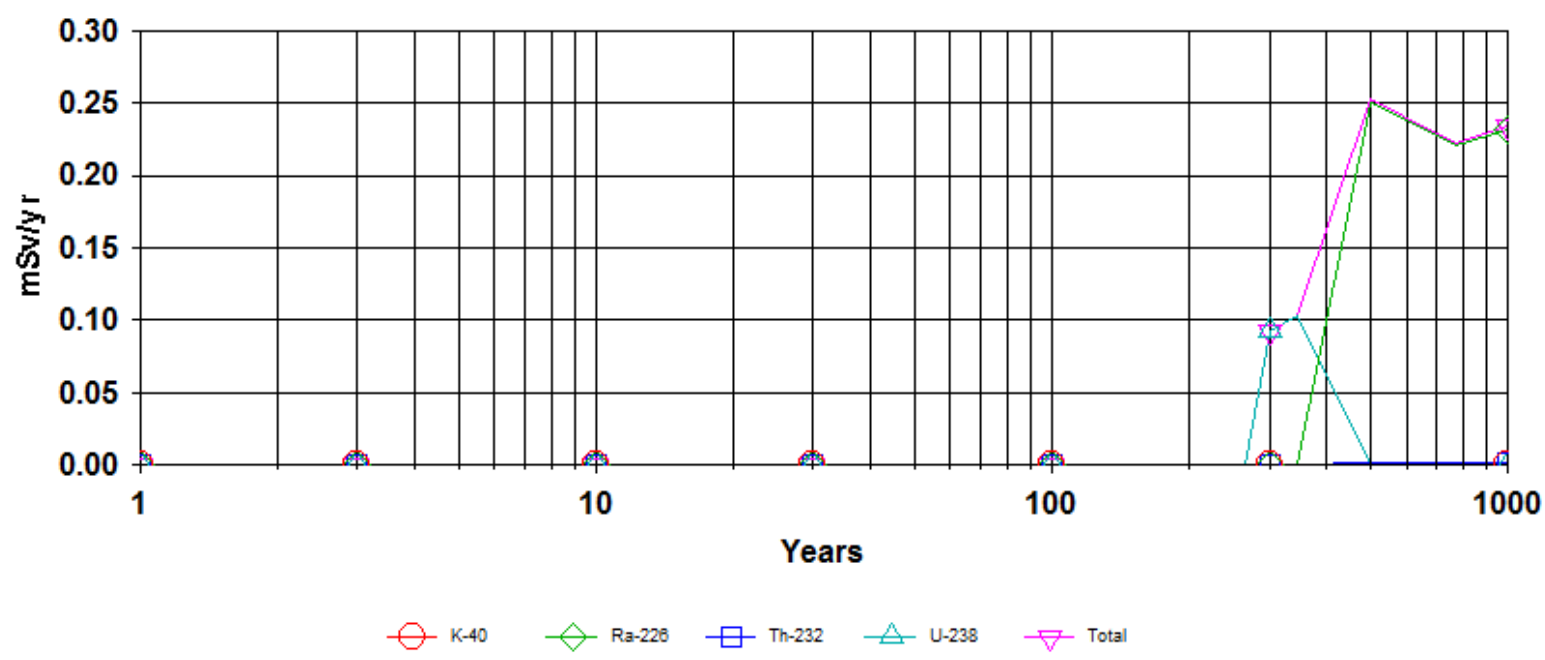

Figure 5. The summed dose due to all nuclides after a clean cover thickness of $1.25 \mathrm{~m}$ was used

The clean cover thickness of $1.25 \mathrm{~m}$ was used to calculate the level of clean-up of the contaminated site (Tudor Shaft). Based on this clean up cover thickness, the maximum total dose of $2.52 \mathrm{E}-01 \mathrm{mSv} / \mathrm{yr}$ was observed at $\mathrm{t}=$ $500 \pm 1$ years. As seen in Figure 5, the contaminated site under investigation with initial total maximum dose of 
$1.63 \pm 1.0 \mathrm{mSv} / \mathrm{yr}$ for all pathways has been cleaned to a dose lower to $0.001 \mathrm{mSv} / \mathrm{yr}$ for a period of 1 to $500 \mathrm{yrs}$ before it peak at $500 \mathrm{yrs}$ to a dose $(2.52 \mathrm{E}-01 \mathrm{mSv} / \mathrm{yr})$ compared to the basic radiation dose limit (BRDL) of $0.25 \mathrm{mSv} / \mathrm{yr}$.

\section{Conclusion}

The RESRAD-onsite 7.2 code has been used to complete environmental risk assessment in Tudor shaft contaminated site of an area of $10 \mathrm{~km}^{2}$. The maximum total dose of $1.639 \mathrm{mSv} / \mathrm{yr}$ was obtain at $\mathrm{t}=8.17 \pm 0.02$ years with the meat, milk and soil pathways-total dose contributions of 1.496E-02 $\pm 0.0091,1.547 \mathrm{E}-02 \pm 0.0094$, $1.838 \mathrm{E}-02 \pm 0.0112 \mathrm{mSv} / \mathrm{yr}$ respectively. The total peak dose at time $\mathrm{t}=0 \mathrm{yr}$. is $1.63 \pm 1.0 \mathrm{mSv} / \mathrm{yr}$ for all pathways and is 6.53 times higher compare to the basic radiation dose limit of $2.5 \mathrm{E}-01 \mathrm{mSv} / \mathrm{yr}$ with ${ }^{226} \mathrm{Ra}$ contributing $99.1 \%$. The total excess cancer risk value of $3.46 \mathrm{E}-3$ is 10 times the limit of $3 \times 10^{-4}$ obtained using BRDL. A cover clean-up layer of $1.25 \mathrm{~m}$ was used to achieve lower dose of $0.001 \mathrm{mSv} / \mathrm{yr}$ for a period of 1 to 500 yrs before it peak at $500 \mathrm{yrs}$ to a dose $(2.52 \mathrm{E}-01 \mathrm{mSv} / \mathrm{yr})$ compared to the basic radiation dose limit (BRDL) of $0.25 \mathrm{mSv} / \mathrm{yr}$.

\section{Acknowledgement}

The authors acknowledged the Centre for Applied Radiation Science and Technology, North-west University, Mafikeng, for providing the fund used in the intensive RESRAD family of code training in Argonne National Laboratory, United States Department of Energy, Illinois, Chicago.

\section{References}

Bellamy, M., Finklea, L., Dolislager, F., \& Eckerman, K. (2014). Area Correction Factors for Contaminated Soil for Use in Risk and Dose Assessment Models, ORNL/TM-2013/00, September, Oak Ridge National Laboratory, Oak Ridge, Tenn.

Clapp, R. B., \& Hornberger, G. M. (1978). Empirical equations for some soil hydraulic properties. Water resources research, 14(4), 601-604.

Eckerman, K. F., \& Ryman, J. C. (1996). External exposure to radionuclides in air, water, and soil (No. CONF-960415--36). Oak Ridge National Lab.

Eckerman, K. F., \& Ryman, J. C. (1996). External exposure to radionuclides in air, water, and soil (No. CONF-960415--36). Oak Ridge National Lab..

Gil-García, C., Tagami, K., Uchida, S., Rigol, A., \& Vidal, M. (2009). New best estimates for radionuclide solid-liquid distribution coefficients in soils. Part 3: miscellany of radionuclides ( $\mathrm{Cd}, \mathrm{Co}, \mathrm{Ni}, \mathrm{Zn}, \mathrm{I}, \mathrm{Se}, \mathrm{Sb}, \mathrm{Pu}$, Am, and others). Journal of Environmental Radioactivity, 100(9), 704-715.

ICRP. (2008). Nuclear Decay Data for Dosimetric Calculations. Annals of the ICRP, ICRP Publication 107, 38(3). Elsevier.

Kamboj, S., Cheng, J. J., \& Yu, C. (2005). Deterministic vs. probabilistic analyses to identify sensitive parameters in dose assessment using RESRAD. Health physics, 88(5), S104-S109.

Kamboj, S., Gnanapragasam, E., LePoire, D., Biwer, B. M., Cheng, J., Arnish, J., ... \& Thaggard, M. (2002). Probabilistic Approach to identify sensitive parameter distributions in multimedia pathway analysis. Practice Periodical of Hazardous, Toxic, and Radioactive Waste Management, 6(1), 23-30.

Moore, J. W., \& Ramamoorthy, S. (2012). Heavy metals in natural waters: applied monitoring and impact assessment. New York: Springer Science \& Business Media.

NAS (National Academy of Sciences). (1999). Health Effects of Exposure to Radon, National Research Council, Committee on the Health Effects of Exposure to Radon (BEIR VI).

Njinga, R. L., \& Tshivhase, V. M. (2016). Lifetime cancer risk due to gamma radioactivity in soils from Tudor Shaft mine environs, South Africa. Journal of radiation research and applied sciences, 9(3), 310-315.

Turton, A. R., Schultz, C., Buckle, H., Kgomongoe, M., Maluleke, T., \& Drackner, M. (2004, August). Gold, scorched earth and water: The hydropolitics of development in Johannesburg. In Seminar on Water Management in Megacities at the Stockholm Water Symposium (Vol. 15).

Venter, A. J. (1995). Assessment of the effects of gold-mine effluent on the natural aquatic environment (Doctoral dissertation, University of Johannesburg).

Walker, S. A. (2013, July). Revisions to US EPA Superfund Risk and Dose Assessment Models and Guidance-13403. WM Symposia, 1628 E. Southern Avenue, Suite 9-332, Tempe, AZ 85282 (United States). 
Retrieved from http://www.wmsym.org/archives/2013/papers/13403.pdf \& http://www.wmsym.org/archives/2013/panels/103-625.pdf.

Yu, C. (1987). Modeling of low-level-waste disposal for environmental impact analysis (No. CONF-870306--70). Argonne National Lab..

Yu, C. (1999). RESRAD family of codes and comparison with other codes for decontamination and restoration of nuclear facilities. Chapter, 11, 207-231.

$\mathrm{Yu}, \mathrm{C}$. (2007). Modeling radionuclide transport in the environment and assessing risks to humans, flora, and fauna: The RESRAD family of codes. In ACS symposium series (Vol. 945, pp. 58-70). Oxford University Press.

Yu, C. (2007). Tools for Assessing Radiological Doses to Human and Biota. In Radiological Assessment: Detection, Identification, and Evaluation, Health Physics Society Professional Development School Textbook.

Yu, C., LePoire, D., Gnanapragasam, E., Arnish, J., Kamboj, S., Biwer, B. M., ... \& Mo, T. (2000). Development of probabilistic RESRAD 6.0 and RESRAD-BUILD 3.0 computer codes. US Nuclear Regulatory Commission.

Yu, C., Orlandini, K. A., Cheng, J. J., \& Biwer, B. M. (2001). Assessing the impact of hazardous constituents on the mobilization, transport, and fate of radionuclides in RCRA waste disposal units (No. ANL/EAD/TM-93). Argonne National Lab., IL (US).

Yu, C., Zielen, A. J., Cheng, J. J., LePoire, D. J., Gnanapragasam, E., Kamboj, S., ... \& Peterson, H. (2001). User's manual for RESRAD version 6. Oak Ridge, TN: US Department of Energy Office of Scientific and Technical Information.

\section{Copyrights}

Copyright for this article is retained by the author(s), with first publication rights granted to the journal.

This is an open-access article distributed under the terms and conditions of the Creative Commons Attribution license (http://creativecommons.org/licenses/by/4.0/). 